African Crop Science Journal by African Crop Science Society is licensed under a Creative Commons Attribution 3.0 Uganda License. Based on a work at www.ajol.info/ and www.bioline.org.br/cs DOI: http://dx.doi.org/10.4314/acsj.v24i1.3S

\title{
DEVELOPMENT OF WHEAT GERMPLASM FOR STEM RUST RESISTANCE IN EASTERN AFRICA
}

\author{
D. WORKU, T. ZERIHUN, K. DANIEL, Z. HABTEMARIAM, A. DAWIT and R.WANYERA \\ Ethiopin Institute of Agricultural Research (EIAR), Wheat Regional Center of Excellence, KARC, \\ P. O. Box 489, Addis Ababa, Ethiopia \\ ${ }^{1}$ Kenya Agricultural and Livestock Research Organization (KALRO), Njoro, Private Bag (20107), \\ Njoro, Kenya \\ Corresponding author: workudi@yahoo.com
}

\begin{abstract}
Wheat (Triticum aestivum) rust outbreak is the primary production constraint in Eastern Africa. Ethiopia, Kenya and Uganda are hot spots for the epidemic of rusts, due to higher rates of evolution of new pathogen races, especially of the virulent stem rust (Puccinia graminis) race, Ug99. The objective of this study was to identify sources of resistance to the major pathotypes of stem rust prevalent in some countries of Eastern Africa. Three hundred and six elite breeding lines, selected and advanced at the Wheat Regional Centre of Excellence (WRCoE) in Ethiopia, were planted in stem rust hot spot areas of the country (Arsi-Robe) and Kenya (Njoro) under natural infections. Stem rust scores of 18, 25.8 and 56.2\% of lines at Arsi-Robe; and 35, 49 and 16.7\% of lines at Njoro were resistant to moderately resistant, intermediate and moderately susceptible to susceptible category, respectively. Overall coefficient of infection (ACI) at Arsi-Robe (24) was greater than that of Njoro (13), indicating higher disease pressure in Ethiopia than Kenya. Among the lines, 67\% at Njoro and $49 \%$ at Arsi Robe showed good levels of resistance, with a severity less than $20 \%$. However, only $32 \%$ of the lines showed a good level of resistance $(<20 \%$ severity) in both locations. These lines could have combined resistance to the multiple stem rust races prevailing at both locations. Generally, most of the lines, which showed better resistance at Njoro were susceptible at Arsi-Robe.
\end{abstract}

Key Words: Hot spots, Puccinia graminis, Triticum aestivum

\section{RÉSUMÉ}

La rouille de la tige chez le blé (Triticum aestivum) est l'un des plus importants problèmes rencontres dans la production du blé en Afrique de l'Est. L'Ethiopie, le Kenya et l'Ouganda sont des pays à fort taux d'épidémie de rouille de la tige. Ceci à cause du taux élevé de d'agents pathogènes, ainsi que l'apparition de nouveaux pathogènes, dont le plus redoutable (Puccinia graminis) race Ug99. L'objectif de cette étude était d'identifier des sources de résistance aux pathotypes majeurs de la rouille de tige qui sevit dans certains pays de l'Afrique de l'Est. Trois cent six lignées élites, sélectionnées au centre régionale d'excellence du blé (WRCoE) en Ethiopie, ont été plantées dans des zones a fort taux de prévalence de la rouille de tige en Ethiopie (Arsi-Robe) au Kenya (Njoro). Respectivement, 18, 25.8 et 56.2\% des lignées a Arsi-Robe; et 35, 49 et 16.7\% des lignées a Njoro se sont révélées résistantes ou modérément résistantes, intermédiaires, modérément susceptibles a susceptibles. En somme, le coefficient d'infection (ACI) à Arsi-Robe (24) était plus élevé qu'à Njoro (13), ceci indique que la pression de la rouille de tige est plus élevée en Ethiopie qu'au Kenya. Parmi les lignées évaluées, $67 \%$ à Njoro et $49 \%$ a Arsi Robe sont exhibe des bons niveaux de résistance, avec $20 \%$ de sévérité. Néanmoins, seul $32 \%$ des lignées ont exhibe une bonne résistance ( $<20 \%$ sévérité) dans les deux localités. Ces lignées porteraient surement des gènes 
de résistance multiple contre les différentes races de champignon présents dans les deux localités. Généralement, la plupart des lignées ayant exhibe une bonne résistance a Njoro étaient susceptible a Arsi-Robe.

Mots Clés: Zone a fort taux de prévalence, Puccinia graminis, Triticum aestivum

\section{INTRODUCTION}

Wheat (Triticum aestivum) stem rust, caused by Puccinia graminis f. sp. tritici, is the major biotic constraints for wheat production in the world, and in the Eastern part of Africa in particular. Countries such as Kenya and Ethiopia experience recurrent epidemics of stem rust due to evolution of new stem rust races (Wanyera et al., 2006; Admassu et al., 2009). This has been evidenced in the evolution of new stem rust races, with additional virulence to the deployed stem rust resistance genes in wheat cultivars. For instance, variants with virulence for $\mathrm{Sr} 24$ (Jin et al., 2008) and Sr36 (Jin et al., 2009) genes were detected in Kenya. Similarly, virulence to SrTmp (Olivera et al., 2015) gene was detected from stem rust samples collected during the 2013 season epidemics that wiped out Digalu in Bale zone of Ethiopia. However, the race responsible for the loss of effectiveness of SrTmp gene in Digalu was reported in Turkey (Zafer et al., 2012), prior to its discovery in Ethiopia.

Currently, race Ug99 (TTKSK) is continuously evolving and undergoing stepwise mutations, to bear additional virulence. There are eight variants of this race reported across many parts of Africa (Singh et al., 2015) and its migration and spread to other parts of Africa, Asia and other parts of the world is inevitable (Singh et al., 2011). In view of the recurrent epidemics of stem rust in eastern Africa, an internationally aggressive breeding strategy was followed and resistant cultivars were released in countries most vulnerable to this race. For instance, in Kenya two bread wheat cultivars, Eagle-10 and Robin, were released in 2009 (Njau et al., 2011); and in Ethiopia, Kakaba and Danda'a were released in 2010 as resistant cultivars to Ug99.

Although the release of resistant cultivars to Ug99 has paramount importance for those countries that were at immediate risk of the pathogen, the continuous evolution of new races and/or variants of the same race requires sustainable efforts to deal with epidemics of the kind of Ug99 or the one that wiped out mega bread wheat cultivar Digalu in Ethiopia by the race TKTTF. The objective of this study was to identify sources of resistance to the major pathotypes of stem rust prevalent in some countries of eastern Africa.

\section{MATERIALS AND METHODS}

A total of 306 elite bread wheat lines that were either selected from international nurseries or developed from the WRCoE, including susceptible and resistant checks, were used in the study. Among the cultivars resistant to Ug99 included in the study, were Danda'a, Kakaba and Digalu. The susceptible cultivar, Hawi was also included. Millenium, which carries $\mathrm{Sr} 24$ gene was included in the test to evaluate its performance across the two locations (Arsi Robe in Ethiopia and Njoro in Kenya). These elite bread wheat lines were planted in two rows of 1-metre length.

At Arsi Robe station, there was no artificial inoculation of stem rust, since the disease occurred at epidemic proportions most of the time under natural conditions. However, a spreader row of PBW343 was used to encourage further development of stem rust race Ug99. In Kenya at Njoro, disease development was encouraged by making artificial inoculations at different growth stages of the crop development and spreader rows of super susceptible bread wheat Cacuke, completely susceptible to Ug99 (Kimani et al., 2015) was utilised. When the susceptible check started to show stem rust development, scoring of severity was carried out using the modified Cobb scale (Peterson et al., 1948). Average Coefficients of Infection (ACI) were calculated by taking into account the severity of stem rust of the lines and cultivars, and their field response (Stubbs et al., 1986). The scores were converted into average coefficients of infection, by multiplying severity by an assigned value for the field response, as suggested by Stubbs et al. 
(1986) (Table 1). The constant value was further modified to include infection responses of resistant to moderately resistant $(\mathrm{RMR}=0.3)$ and moderately susceptible to susceptible (MSS=0.9).

\section{RESULTS}

Reactions of elite lines. Out of the 306 lines tested at Arsi Robe, ten were immune to the pathogen populations (Table 2). However, at

TABLE 1. Field response values according to Stubbs et al. (1986) with some modifications

\begin{tabular}{lcc}
\hline Field response & Symbol & Constant value \\
\hline Zero(Very resistant) & 0 & 0 \\
Resistant & R & 0.2 \\
Resistant to moderately & RMR & 0.3 \\
resistant & & \\
Moderately resistant & MR & 0.4 \\
Intermediate & M (MRMS) & 0.6 \\
Moderately susceptible & MS & 0.8 \\
Moderately susceptible to & MSS & 0.9 \\
susceptible & & 1.0 \\
Susceptible & S & \\
\hline
\end{tabular}

$\mathrm{R}=$ resistant, $\mathrm{RMR}=$ resistant to moderately resistant, $\mathrm{MR}=$ moderately resistant, $M=$ moderately resistant to moderately susceptible, MS = moderately susceptible, $\mathrm{MSS}=$ moderately susceptible to susceptible and $S$ = susceptible

TABLE 2. Number of elite bread wheat lines in resistance and susceptibility categories in Ethiopia and Kenya

\begin{tabular}{llcc}
\hline No. & $\begin{array}{l}\text { Reaction } \\
\text { category }\end{array}$ & \multicolumn{2}{c}{ Number of lines } \\
\cline { 3 - 4 } & & Arsi Robe & Njoro \\
\hline 1 & 0 & 10 & 0 \\
2 & R & 11 & 4 \\
3 & RMR & 5 & 12 \\
4 & MR & 29 & 91 \\
5 & M & 79 & 150 \\
6 & MS & 31 & 24 \\
7 & MSS & 45 & 16 \\
8 & S & 96 & 9 \\
\hline
\end{tabular}

$\mathrm{R}=$ resistant, $\mathrm{RMR}=$ resistant to moderately resistant, $\mathrm{MR}=$ moderately resistant, $M=$ moderately resistant to moderately susceptible, MS= moderately susceptible MSS= moderately susceptible to susceptible and $S=$ susceptible
Njoro, none of the lines were immune to stem rust infection. Eleven lines were resistant at Arsi Robe, but only four lines were resistant at Njoro. Five and 12 lines displayed resistant to moderately resistant reactions at Arsi Robe and Njoro, respectively. Twenty nine lines at Arsi Robe and 91 lines at Njoro exhibited moderately resistant reactions; whereas 79 and 150 lines displayed intermediate reactions at Arsi Robe and Njoro, respectively. Thirty one lines at Arsi Robe showed moderately susceptible reactions, and 24 at Njoro. With respect to moderately susceptible to susceptible reactions (MSS), (45), displayed this reaction at Arsi Robe. However, only 16 lines displayed MSS reactions at Njoro.

Ninety-six lines were completely susceptible at Arsi Robe and only nine lines were susceptible at Njoro. In general, considering the disease reactions at Arsi Robe and Njoro, more lines were in the moderately susceptible and susceptible categories at Arsi Robe than at Njoro (Fig. 1 and Table 3). However, in reaction categories ranging from resistant to intermediate, the number of lines at Njoro exceeded by far the number of lines at Arsi Robe (Fig. 1 and Table 3).

Severity of stem rust. About half of the elite lines (151) tested at Arsi Robe (Fig. 2) showed a severity less than or equal to $20 \%$; whereas at Njoro, almost two-third of the lines (204) showed the same severity levels (Fig. 2). Twenty one and $20 \%$ of the lines showed a severity of $25-30 \%$ at Arsi Robe and Njoro, respectively. Ninety one (30\%) of the lines at Arsi Robe and 42 (14\%) of the lines at Njoro displayed a severity of greater than $30 \%$.

Terminal stem rust severity, and coefficient of infection. Considering the three parameters, the highest score was recorded for bread wheat cultivar Hawi (Table 3). The least score was recorded for elite bread wheat line ETBW6655 (Table 3). Five elite lines depicted an average coefficient of infection (ACI) value of less than two. These included lines ETBW6261, ETBW6406, ETBW6680, ETBW6681 and ETBW6690. Generally $67(83 \%)$ of the test genotypes displayed an ACI value of less than or equals to ten. However, $11(13 \%)$ of the 


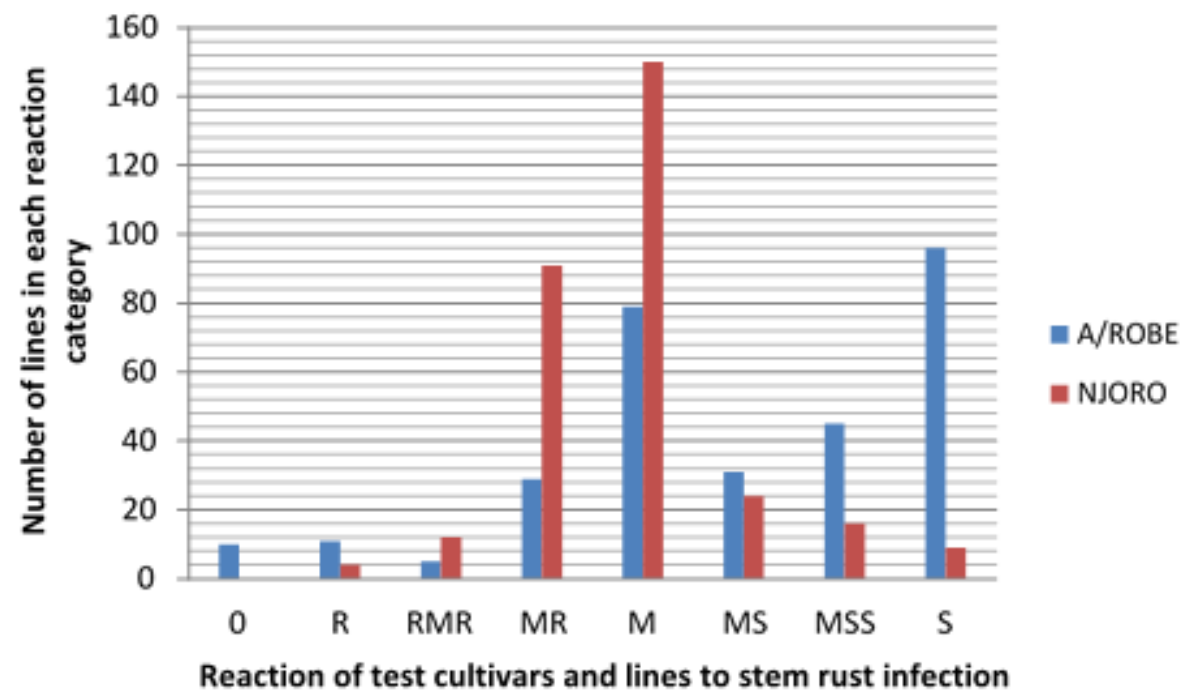

Figure 1. Number of bread wheat elite lines in different classes of stem rust reactions at Arsi Robe in Ethiopia and Njoro in Kenya in 2012.

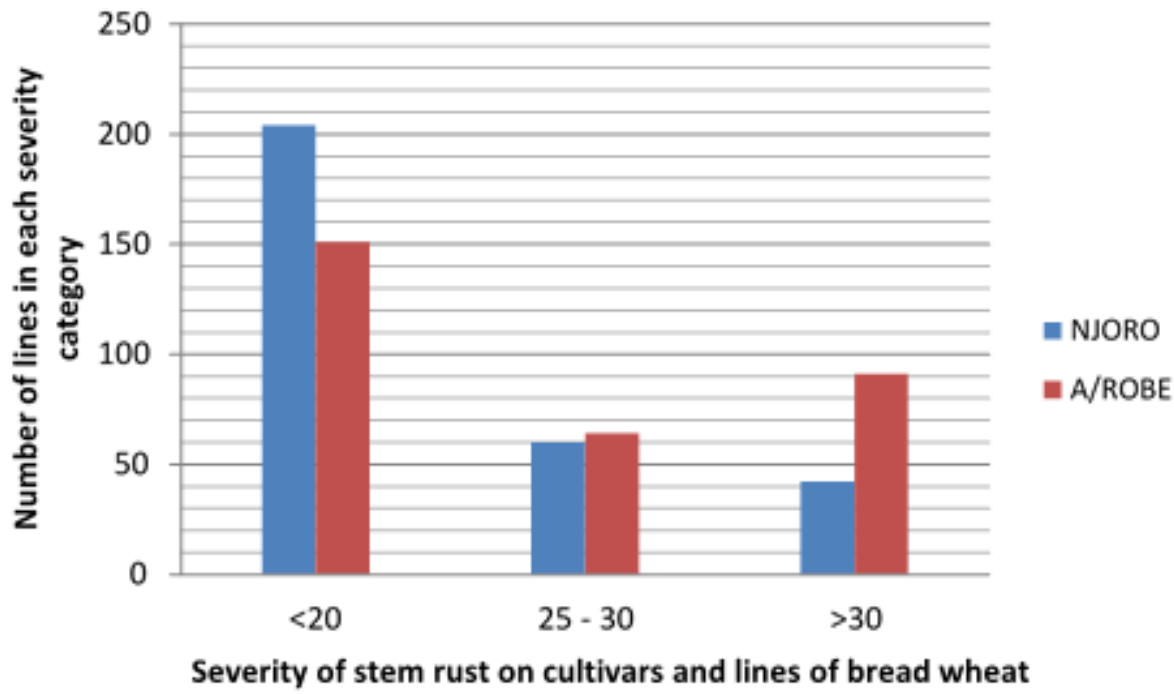

Figure 2. Elite lines of bread wheat evaluated in Ethiopia and Kenya and their severity levels.

genotypes showed ACI value of greater than or equals to ten.

\section{DISCUSSION}

The variability in both severity and infection response of elite lines, and check cultivars at both testing locations, Arsi Robe and Njoro (Tables 2 and 3 ), clearly shows that the stem rust pathogen populations have differences in their virulence profiles. More lines were found to be more susceptible at Arsi Robe (Ethiopia) than at Njoro (Kenya). Cheruiyot et al. (2015) reported Narok as the most stem rust prone compared to Njoro in Kenya. In the present study, more lines were found resistant, which could be attributed to the low initial stem rust pressure compared with Arsi Robe in Ethiopia. During the 2012 season, stem rust race analysis reports depicted the dominance of race TTKSK across many wheat growing areas 
TABLE 3. Terminal stem rust severity, coefficient of infection and average coefficient of infection of selected elite wheat lines and check cultivars in Ethiopia and Kenya

\begin{tabular}{|c|c|c|c|c|c|c|c|c|c|c|c|c|c|}
\hline \multirow[t]{2}{*}{ Entry } & \multirow[t]{2}{*}{ Genotype } & \multicolumn{2}{|c|}{ Terminal stem rust severity } & \multicolumn{2}{|c|}{ Cl-value } & \multirow{2}{*}{$\begin{array}{l}\mathrm{ACl} \\
\text { value }\end{array}$} & \multirow[t]{2}{*}{ Entry } & \multirow[t]{2}{*}{ Genotype } & \multicolumn{2}{|c|}{ Terminal stem rust severity } & \multicolumn{2}{|c|}{ Cl-value } & \multirow{2}{*}{$\begin{array}{l}\mathrm{ACl} \\
\text { value }\end{array}$} \\
\hline & & Njoro & Arsi Robe & Njoro & Arsi Robe & & & & Njoro & Arsi Robe & Njoro & Arsi Robe & \\
\hline 1 & Danda'a & tMR & $10 \mathrm{M}$ & 0.4 & 6 & 3.2 & 193 & ETBW 6664 & 5RMR & $5 \mathrm{MSS}$ & 1.5 & 4.5 & 3 \\
\hline 2 & ETBW 6432 & $t R$ & $20 \mathrm{MS}$ & 0.2 & 16 & 8.1 & 194 & ETBW 6668 & $10 \mathrm{MR}$ & $20 \mathrm{M}$ & 4 & 12 & 8 \\
\hline 3 & ETBW 6434 & $10 \mathrm{M}$ & $15 \mathrm{M}$ & 6 & 9 & 7.5 & 196 & ETBW 6679 & $5 \mathrm{MR}$ & $20 \mathrm{M}$ & 2 & 12 & 7 \\
\hline 5 & ETBW 6440 & $t R$ & $10 \mathrm{M}$ & 0.2 & 6 & 3.1 & 197 & ETBW 6681 & $5 \mathrm{MR}$ & 0 & 2 & 0 & 1 \\
\hline 7 & ETBW 6468 & $5 \mathrm{MS}$ & $5 \mathrm{MR}$ & 4 & 2 & 3 & 198 & ETBW 6689 & $10 \mathrm{MR}$ & $5 \mathrm{M}$ & 4 & 3 & 3.5 \\
\hline 8 & ETBW 6469 & $10 \mathrm{MS}$ & $5 \mathrm{M}$ & 8 & 3 & 5.5 & 200 & ETBW 6219 & $20 \mathrm{M}$ & $10 \mathrm{M}$ & 12 & 6 & 9 \\
\hline 16 & ETBW 6491 & 10MR & 10RMR & 4 & 3 & 3.5 & 202 & ETBW 6238 & $20 \mathrm{MR}$ & $5 \mathrm{M}$ & 8 & 3 & 5.5 \\
\hline 17 & ETBW 6493 & 10RMR & 20MSS & 3 & 18 & 10.5 & 204 & ETBW 6281 & $15 \mathrm{MR}$ & $5 \mathrm{M}$ & 6 & 3 & 4.5 \\
\hline 18 & ETBW 6499 & $15 \mathrm{MR}$ & $10 \mathrm{MR}$ & 6 & 4 & 5 & 206 & ETBW 6453 & $20 \mathrm{M}$ & tMR & 12 & 0.4 & 6.2 \\
\hline 28 & ETBW 6142 & $20 \mathrm{M}$ & MS & 12 & 0.8 & 6.4 & 207 & ETBW 6474 & $15 \mathrm{M}$ & $10 \mathrm{M}$ & 9 & 6 & 7.5 \\
\hline 47 & ETBW 6133 & $20 \mathrm{M}$ & $15 \mathrm{M}$ & 12 & 9 & 10.5 & 210 & ETBW 6506 & $10 \mathrm{MR}$ & $10 \mathrm{M}$ & 4 & 6 & 5 \\
\hline 48 & ETBW 6145 & $20 \mathrm{MR}$ & $t R$ & 8 & 0.2 & 4.1 & 211 & ETBW 6523 & $15 \mathrm{MS}$ & $10 \mathrm{M}$ & 12 & 6 & 9 \\
\hline 50 & ETBW 6158 & $10 \mathrm{MR}$ & $20 \mathrm{MS}$ & 4 & 16 & 10 & 213 & ETBW 6530 & $10 \mathrm{M}$ & $5 \mathrm{M}$ & 6 & 3 & 4.5 \\
\hline 53 & ETBW 6173 & $5 \mathrm{M}$ & 20MSS & 3 & 18 & 10.5 & 215 & ETBW 6534 & $15 \mathrm{MR}$ & $20 \mathrm{M}$ & 6 & 12 & 9 \\
\hline 54 & ETBW 6181 & $20 \mathrm{M}$ & tR & 12 & 0.2 & 6.1 & 216 & ETBW 6543 & $20 \mathrm{M}$ & $15 \mathrm{M}$ & 12 & 9 & 10.5 \\
\hline 55 & ETBW 6183 & $20 \mathrm{M}$ & $\mathrm{tR}$ & 12 & 0.2 & 6.1 & 217 & ETBW 6655 & 5RMR & 0 & 1.5 & 0 & 0.75 \\
\hline 60 & ETBW 6300 & $10 \mathrm{M}$ & $5 \mathrm{MSS}$ & 6 & 4.5 & 5.25 & 218 & ETBW 6682 & $15 \mathrm{MR}$ & $5 \mathrm{MR}$ & 6 & 2 & 4 \\
\hline 61 & ETBW 6317 & $20 \mathrm{MS}$ & $10 \mathrm{M}$ & 16 & 6 & 11 & 219 & ETBW 6690 & $20 \mathrm{M}$ & 0 & 12 & 0 & 6 \\
\hline 62 & ETBW 6320 & $10 \mathrm{MS}$ & $5 R$ & 8 & 1 & 4.5 & 221 & ETBW 6256 & $5 \mathrm{MR}$ & tMR & 2 & 0.4 & 1.2 \\
\hline 65 & ETBW 6355 & 10RMR & $20 M S S$ & 3 & 18 & 10.5 & 224 & ETBW 6278 & $20 \mathrm{M}$ & $10 \mathrm{M}$ & 12 & 6 & 9 \\
\hline 69 & ETBW 6216 & $10 \mathrm{M}$ & $10 \mathrm{MS}$ & 6 & 8 & 7 & 227 & ETBW 6445 & $20 \mathrm{M}$ & $10 \mathrm{M}$ & 12 & 6 & 9 \\
\hline 86 & ETBW 6488 & $20 \mathrm{M}$ & tMR & 12 & 0.4 & 6.2 & 234 & ETBW 6651 & $10 \mathrm{MR}$ & $10 \mathrm{M}$ & 4 & 6 & 5 \\
\hline 87 & ETBW 6653 & $20 \mathrm{MR}$ & tRMR & 8 & 0.3 & 4.15 & 238 & ETBW 6674 & $10 \mathrm{MR}$ & tMSS & 4 & 0.9 & 2.45 \\
\hline 88 & ETBW 6654 & $10 \mathrm{MR}$ & $20 \mathrm{M}$ & 4 & 12 & 8 & 239 & ETBW 6686 & $20 \mathrm{MR}$ & $5 \mathrm{MSS}$ & 8 & 4.5 & 6.25 \\
\hline 90 & ETBW 6197 & $20 \mathrm{MR}$ & $20 \mathrm{M}$ & 8 & 12 & 10 & 243 & ETBW 6702 & 5RMR & $10 \mathrm{MS}$ & 1.5 & 8 & 4.75 \\
\hline 98 & ETBW 6261 & tR,5MS & $5 \mathrm{MR}$ & 0.2 & 2 & 1.1 & 244 & Digalu & $10 \mathrm{MR}$ & $20 \mathrm{M}$ & 4 & 12 & 8 \\
\hline 99 & ETBW 6264 & $20 \mathrm{M}$ & $10 \mathrm{MSS}$ & 12 & 9 & 10.5 & 245 & Kakaba & $15 \mathrm{MR}$ & $20 \mathrm{M}$ & 6 & 12 & 9 \\
\hline 100 & ETBW 6266 & $5 \mathrm{MS}$ & $5 \mathrm{MR}$ & 4 & 2 & 3 & 259 & ETBW 6177 & $20 \mathrm{M}$ & $20 \mathrm{M}$ & 12 & 12 & 12 \\
\hline 103 & ETBW 6457 & $20 \mathrm{M}$ & $10 \mathrm{M}$ & 12 & 6 & 9 & 283 & ETBW 6384 & $15 \mathrm{M}$ & $20 \mathrm{M}$ & 9 & 12 & 10.5 \\
\hline 105 & ETBW 6461 & $20 \mathrm{M}$ & $5 \mathrm{MR}$ & 12 & 2 & 7 & 290 & Hawi & $30 \mathrm{MR}$ & $50 S$ & 12 & 50 & 31 \\
\hline
\end{tabular}


in Ethiopia, including the current testing site, viz. Arsi Robe (Woldeab et al., 2013). The susceptibility of major bread wheat cultivars in the Ethiopian wheat rust trap nursery (EWRTN), during the season at Arsi Robe, is additional evidence for the development of stem rust epidemics (Worku, Unpublished data) and this epidemics occurred on both bread wheat cultivars and durum wheat landraces (Worku, 2014). Ismail et al. (2012) reported race TTKST as the dominant stem rust race in major wheat growing regions of Kenya, because of the widespread production of bread wheat cultivar KS Mwamba. This particular race is still the most dominant stem rust race prevalent in major wheat growing regions of Kenya, and a recent virulence survey in Narok resulted in the identification of race TTKST which is virulent on $\mathrm{Sr} 24$ gene (Stella et al., 2015). The fact that none of the tested lines was immune to stem rust infection at Njoro, and ten lines were immune at Arsi Robe depicts that there could be bread wheat lines that carry effective race-specific seedling stem rust resistance genes, to the pathogen population at Arsi Robe that are not effective to the prevailing stem rust races in Njoro. This further suggests that the races prevalent in Njoro may have a wider virulence spectrum compared to the races in Arsi Robe as three of the Ug99 lineage reported in Kenya (Wanyera et al., 2006; Jin et al., 2008; Jin et al., 2009) and only two of them reported in Ethiopia (Admassu et al., 2009; Getaneh, Unpublished data).

The 73 lines that displayed resistant to moderately resistant reactions to the prevalent races at both Arsi Robe and Njoro (Tables 1 and 3 ), could be potential sources of resistance to race Ug99 and its derivative with virulence for Sr24 gene. The Arsi zone of Ethiopia is a known hotspot for the development of stem rust epidemics and many stem rust race analysis works indicated the presence of broad races with wider virulence spectrum (Admassu and Fekadu, 2005; Admassu et al., 2009); and this recurrent epidemics has resulted in the susceptibility of most tested lines in the current evaluation.

Generally, the Average Coefficient of Infection (ACI) of most elite lines was small compared to the ACI value of the susceptible check, Hawi $(\mathrm{ACI}=31)$. Six lines displayed an ACI value of $<2$. 
The least ACI value was recorded for elite line ETBW6655 (ACI=0.75). Hawi is postulated to have seedling stem rust resistance gene(s), $\mathrm{Sr} 30+/$ Sr31 (Naod et al., 2005), both of which are not effective to the prevalent stem rust races in the major wheat growing regions of Ethiopia (Admassu and Fekadu, 2005; Admassu et al., 2009; Abebe et al., 2012). Bread wheat cultivar ET13A2, was resistant to moderately resistant to the prevalent pathotypes of stem rust in Kenya and Ethiopia. It is, therefore, essential to incorporate such types of bread wheat cultivars as ET13A2 in the regional wheat breeding/ improvement programme as possible sources of stem rust resistance.

The Shuttle-Breeding Programme between Mexico and Kenya has resulted in the identification and development of high-yielding and stem rust resistant bread wheat lines, with a high level of APR to the prevailing stem rust races in Kenya and other countries of Africa (Singh et al., 2012). Taking the success of CIMMYT's shuttle breeding strategy, a shuttle breeding programme was initiated between Ethiopia and Kenya that resulted in the identification and development of stem rust resistant and high yielding bread wheat lines that fit in the agroecologies of east Africa countries, such as Tanzania and Uganda. Selection and advancement of breeding lines, with low level of severity (usually $<20 \%$ ), with moderately susceptible or moderately resistant infection types (responses) to the prevailing stem rust races in the test environments is a dependable breeding option to identify resistant wheat lines which has been utilised for wheat improvement in Ethiopia (Bechere et al., 1995).

\section{CONCLUSION}

The 73 lines that displayed low level of stem rust severities and resistant to moderately resistant reactions to the stem rust pathogen populations of both test locations, can directly be utilised as resistant parental lines in the regional wheat breeding programme, or they can be advanced to regional yield trials for the development of high yielding and stem rust resistant cultivars to combat with the ever evolving races of stem rust.

\section{ACKNOWLEDGEMENT}

The authors thank the Wheat Regional Centre of Excellence (WRCoE) under the Eastern Africa Agricultural Productivity Project (EAAPP) for funding this research work. The collaborating institutions of the Ethiopian Institute of Agricultural Research (EIAR) and Kenya Agricultural and Livestock Research Organization (KALRO) are grateful. The Association for Strengthening Agricultural Research in Eastern and Central Africa (ASARECA) is acknowledged for facilitating publication of this paper.

\section{REFERENCES}

Abebe, T., Woldeab, G. and Dawit, W. 2012. Distribution and physiologic races of wheat stem rust in Tigray, Ethiopia. Journal of Plant Pathology and Microbiology 3:142. doi:10.4172/2157-7471.1000142.

Admassu, B. and Fekadu, E. 2005. Physiological races and virulence diversity of Puccinia graminis f. sp. tritici on wheat in Ethiopia. Phytopathology Mediterranean 44: 313-318.

Admassu, B. Lind, V., Friedt, W. and Ordon, F. 2009. Virulence analysis of Puccinia graminis f.sp. tritici populations in Ethiopia with special consideration of Ug99. Plant Pathology 58: 362-369.

Cheruiyot, D., Ojwang, P.P.O., Njau, P.N., Arama, P.F. and Bhavani, S. 2015. Evaluation of advanced wheat (Triticum aestivum $\mathrm{L}$.) lines for stem rust (Puccinia graminis f. sp. tritici) resistance and yield. International Journal of Agronomy and Agricultural Research 6 (3): 57-70.

Bechere, E., Tessema, T., Huluka, M. and Andenow, Y. 1995. Breeding durum wheat for resistance to leaf and stem rusts in Ethiopia. In: Proceedings of a Regional Workshop for Eastern, Central and Southern Africa. Njoro, Kenya, October 2-6, 1994. Breeding for disease resistance with emphasis on durability. In: Danial, D.L. (Ed.). Plant Breeding Department, Agricultural University, Wageningen, The Netherlands. pp. 125-132. 
Ismail, S.G., Kinyua, A.M., Kibe., A.M. and Wagara, I.N. 2012. Wheat stem rust severity and physiological races in North Rift region of Kenya. Asian Journal of Plant Pathology 6(2): 25-32.

Jin, Y., Szabo, L.J., Pretorius, Z.A., Singh, R.P., Ward, R. and Fetch, T.J. 2008. Detection of virulence to resistance gene $\mathrm{Sr} 24$ within race TTKS of Puccinia graminis f. sp.tritici. Plant Disease 92: 923-926.

Jin, Y., Szabo, L.J., Rouse, M.N., Fetch T.Jr, Pretorious, Z.A., Wanyera, R. and Njau, P. 2009. Detection of virulence to resistance gene Sr36 within the TTKS race lineage of Puccinia graminis f.sp. tritici. Plant Disease 93: 367-370.

Kimani, N.C, Onguso, J. and Njau, P. 2015. Screening of Kenyan bread wheat varieties for resistance to the emerging strains of stem rust fungi (Puccinia graminis f. sp. tritici) Race Ug99. World Journal of Agricultural Research (3)1: 5-10.

Njau, P.N, Wanyera, R., Singh, D., Singh, R. and Gethi, M. 2011. Release of stem rust resistant wheat varieties for commercial production in Kenya. Journal of Agricultural Science and Technology A1: 587-598.

Naod Betesellassie, Chemeda Fininsa and Ayele Badebo. 2005. The resistance spectra and postulated $\mathrm{Sr}$ genes of Ethiopian hexaploid and tetraploid wheat cultivars. In: Proceedings of the $10^{\text {th }}$ Annual Conference of the Crop Protection Society of Ethiopia, 1112 August 2005. Ethiopian Agricultural Research Organization (EARO), Addis Ababa. Program and Abstracts. pp. 14-15.

Olivera, P. D., Newcomb, M., Szabo, L. J., Rouse, M. N., Johnson, J., Gale, S., Luster, D. G., Hodson, D., Cox, J. A., Burgin, L., Hort, M., Gilligan, C. A., Patpour, M., Justesen, A. F., Hovmoller, M. S., Woldeab, G., Hailu, E., Hundie, B., Tadesse, K., Pumphrey, M., Singh, R. P. and Jin, Y. 2015. Phenotypic and genotypic characterization of race TKTTF of Puccinia graminis f. sp. tritici that caused a wheat stem rust epidemic in southern Ethiopia in 2013-14. Phytopathology 105: 917-928.

Peterson, R.F., Campbell, A.B. and Hannah, A.E. 1948. A diagrammatic scale for estimating rust intensity of leaves and stems of cereals. Canadian Journal of Research 60: 496-500.

Singh, R. P., Hodson, D. P., Jin, Y., Lagudah, E. S., Ayliffe, M. A., Bhavani, S., Rouse, M. N., Pretotious, Z. A., Szabo, L. J., Huerta-Espino, J., Basnet, B. R., Lan, C. and Hovmoller, M. S. 2015. Emergence and spread of new races of wheat stem rust fungus: Continued threat to food security and prospects of genetic control. Phytopathology 105: 872-884.

Singh, R. P., Hodson, D. P., Huerta-Espino, J., Jin, Y., Bhavani, S., Njau, P., Herrera-Foessel, S., Singh, P. K., Singh, S. and Govindan, V. 2011. The emergence of $\mathrm{Ug} 99$ races of the stem rust fungus is a threat to world wheat production. Annual Review of Phytopathology 49: 465481.

Singh, R.P., Herrera-Foessel, S., Huerta-Espino, J., Singh, S., Bhavani, S., Lan, C. and Basnet, B.R. 2012. Progress towards genetics and breeding for minor genes based resistance to Ug99 and other rusts in CIMMYT high yielding wheat. Journal of Integrative Agriculture 13 (2): 255-261.

Stella, C. K., Nathan, M. O., Mercy, N. W., Peter, N. N. and Salinah, R.J. 2015. Race analysis of stem rust inoculum and its virulence on commercial wheat varieties at seedling in KARI-Njoro, Kenya. Asian Journal of Agriculture and Food Sciences 3 (4): 401404.

Stubbs, R.W., Prescott, J.M., Saari, E.E. and Dubin, H.J. 1986. Cereal Disease Methodology Manual. Centro Internacional de Mejoramiento de Maiz y Trigo (CIMMYT), México. 46 p.

Wanyera, R., Kinuyua, M. G., Jin, Y. and Singh, R. P. 2006. The spread of Puccinia graminis $\mathrm{f}$. sp. tritici with virulence on Sr31 in Eastern Africa. Plant Disease 90:113.

Woldeab, G., Hailu, E., Hundie, B., Denbel, W. Badebo, A., Kassa, B., Abebe, T., Mekonen, A., Bitew, B., Taye, T., Hondoro, F., Hodson, D., Hussein, T., Zegeye, W., Girma, G., Gebrekidan, T. and Girma, B. 2013. Wheat rusts: Distribution and virulence analysis of stem rust in the major wheat growing regions of Ethiopia in 2012 and 2013. BGRI 2013 Workshop, New Delhi, India, 19-22, August 2013. 
Worku, D. 2014. Resistance to TTKSK and Zafer, M., Aziz, K., Fazýl, D., Kadir, A. and Lütfi, TTTSK races of Puccinia graminis f. sp. tritici in Ethiopian tetraploid wheat accessions. Journal of Biology, Agriculture and Healthcare 4 (8): 48-53.

Ç. 2012. Determination of Puccinia graminis f. sp. tritici races of wheat in Turkey. Turkish Journal Agriculture and Forestry 36: 107120 